\title{
PENGARUH PROFITABILITAS TERHADAP NILAI PERUSAHAAN FARMASI YANG TERDAFTAR DI BEI PERIODE 2014 SAMPAI 2018
}

\author{
Oleh: \\ Ria Susanti Johan ${ }^{1}$ \\ Desy Septariani ${ }^{2}$ \\ Program Studi Pendidikan Ekonomi \\ Fakultas Ilmu Pendidikan dan Pengetahuan Sosial \\ Universitas Indraprasta PGRI \\ Email: \\ ria.johan7@gmail.com \\ desy.septa@gmail.com
}

\begin{abstract}
ABSTRAK
Penelitian ini bertujuan untuk mengetahui pengaruh profitabilitas yang diproksikan dengan return on equtiity terhadap nilai perusahaan dengan proksi Price To Book Value pada perusahaan Farmasi yang terdaftar di BEI perode 2014 hingga 2018. Populasi dari penelitian ini semua perusahan farmasi yang terdaftar di BEI. Metode pengambilan sampel adalah cluster sampling, dimana 8 perusahaan farmasi terpilih sebagai sampel. Metode analisis data yang digunakan adalah analisis regresi linear sederhana. Hasil penelitian Return on Equity tidak berpengaruh signifikan terhadap Price To Book Value perusahaan farmasi di BEI tahun 2014 sampai 2018.
\end{abstract}

Kata kunci: Profitabilitas dan Nilai Perusahaan

\begin{abstract}
This research is to test the effect of profitability with proxy Return on Equity to firm value with proxy Price To Book Value at pharmaceutical companies listed in Indonesian stack exchange for period 2014 to 2018. Population of this research are all companies listed in Indonesian Stock Exchange. Sampling method uses cluster sampling method, in which 8 pharmaceutical companies were selected as samples. The data are analyses with simple linear regression. The results indicated that Return on Equity does not have significant influence to words Price To Book Value at pharmaceutical companies listed in Indonesian stack exchange for period 2014 until 2018.
\end{abstract}

Keywords: Profitability and Firm Value 


\section{A. PENDAHULUAN}

Di Indonesia sudah banyak perusahaan yang telah go public atau yang sudah tercatat pada Bursa Efek Indonesia (BEI). Salah satunya adalah perusahaan manufaktur pada sektor usaha industri farmasi. Tujuan utama perusahaan go public di antaranya untuk memberikan peluang kepada perusahaan dalam memperoleh tambahan dana jangka panjang, memperbaiki nilai perusahaan, menaikkan citra dari perusahaan, menambah komitmen karyawan perusahaan, berusaha untuk menjaga kelangsungan usaha, dan diperolehnya keringanan atau pembebasan pajak dari pemerintah. Perubahan kedudukan perusahaan menjadi go public adalah salah satu alternatif untuk mendapatkan dana tambahan melalui investor atau masyarakat yang berminat dengan saham yang ditawarkan.

Pada saat ini persaingan bisnis semakin ketat, hal ini mendorong perusahaan untuk dapat bersaing dalam meningkatkan nilai perusahaan. Nilai perusahaan atau yang dikenal dengan firm value menurut Hermuningsih (2012) dan Hendri (2010) dalam (Hauteas \& Muslichah, 2019) adalah pandangan investor mengenai perusahaan yang berhubungan dengan harga pasar. Apabila perusahaan ingin dijual, maka calon investor akan membayar perusahaan tersebut sesuai dengan nilai perusahaannya. Salah satu cara untuk mengukur nilai perusahaan adalah dengan melihat kestabilan dari harga saham yang mengalami kenaikan dalam jangka panjang. Perusahaan yang memiliki harga saham yang tinggi maka nilai perusahaannya juga akan tinggi (Yansi, Rinnaya Ista Rita Andini, 2016).

Dalam penelitian ini, nilai perusahaan diwakilkan dengan rasio harga saham terhadap nilai buku perusahaa atau Price To Book Value (PBV). Price To Book Value (PBV) merupakan salah satu rasio perbandingan harga saham dan nilai buku ekuitas yang dimiliki oleh perusahaan dengan melakukan pengukuran berdasarkan nilai yang diperoleh manajemen dan perusahaan yang terus berkembang dari pihak pasar. PBV juga dijadikan sebagai salah satu indikator dalam menilai saham relatif terhadap harga pasar sahamnya. PBV menunjukkan tingkat kemampuan perusahaan menciptakan nilai relatif terhadap jumlah modal yang diinvestasikan. Tingginya nilai PBV menggambarkan bahwa harga saham juga tinggi dibandingkan nilai buku perlembar saham. Harga saham yang tinggi menggambarkan bahwa perusahaan telah sukses memberikan nilai untuk pemegang saham atau investor (Fernandes Moniaga, 2013).

Nilai perusahaan merupakan kondisi yang telah berhasil diraih oleh sebuah perusahaan yang dapat mencerminkan besar kecilnya perusahaan tersebut. Menurut Indriyani (2017:335) dalam (Rukmawanti et al., 2019) Semakin besar ukuran sebuah perusahaan, artinya perusahaan tersebut sudah sukses memberikan nilai untuk pemegang sahamnya. Ada dua faktor utama yang menentukan nilai perusahaan yaitu yang pertama ukuran perusahaan yang mencerminkan besar kecilnya perusahaan tersebut dan yang kedua adalah profitabilitas yang mencerminkan usaha dari perusahaan dalam mewujudkan profit pada tahun tertentu. Semakin tinggi nilai profitabilitas yang dihasilkan perusahaan, maka akan meningkatkan pengembalian investasi untuk pemegang saham dan dapat menarik keinginan investor untuk berinvestasi. Pendapat (Indriawati et al., 2018) menjelaskan bahwa nilai perusahaan juga ditentukan oleh profitabilitas, keputusan 
investasi, dan pertumbuhan perusahaan yang merupakan faktor dari dalam perusahaan atau internal.

Profitabilitas adalah salah satu indikator dalam memberikan penilaian terhadap perusahaan dalam menciptakan profit pada satu periode akuntansi. Besar kecilnya keuntungan yang dicapai perusahaan akan mencerminkan kinerja perusahaan. Semakin meningkat keuntungan yang dihasilkan, maka para investor akan beropini bahwa perusahaan telah efisien menggunakan aset yang dimiliki. Menurut (Lubis et al., 2017) profitabilitas perusahaan bisa dinilai dengan rasio return on asset (ROA), Return on Equity (ROE), dan return on investment (ROI). Salah satu indikator untuk mengukur profitabilitas perusahaan adalah dengan rasio Return on Equity (ROE), yaitu Net income after tax dibagi dengan total ekuitas dan ROE memiliki hubungan yang kuat dengan PBV. Nilai profitabilitas yang tinggi mencerminkan prospek perusahaan yang baik dan dapat mendorong pemilik modal atau investor untuk turut serta meningkatkan permintaan sahamnya. Dengan meningkatnya permintaan saham maka nilai perusahaan juga mengalami peningkatan (Deborah \& Marsudi, 2013).

Harmono (2015) dalam (Ndruru et al., 2020), menjelaskan bahwa ukuran profitabilitas mempunyai ikatan kualitas dengan nilai perusahaan. Ikatan ini menggambarkan bahwa jika prestasi yang dihasilkan pihak manajemen perusahaan dalam keadaan baik, akan berpengaruh positif terhadap keputusan pemodal di pasar modal untuk berinvestasi.

Penelitian tentang Profitabilitas dan PBV sebelumnya telah dilakukan beberapa orang di antaranya, yang pertama (Wibowo \& Aisjah, 2011) tentang pengaruh profitabilitas, kepemilikan manajerial, kebijakan dividen dan leverage terhadap nilai perusahaan manufaktur yang terdaftar di BEI tahun 2009 sampai 2011. Penelitiannya menghasilkan bahwa profitabilitas yang diproksikan melalui return on assets (ROA) tidak berpengaruh terhadap nilai perusahaan. Kedua, penelitian yang dilakukan (Oktaviarni et al., 2019) yang menghasilkan bahwa profitabilitas menjadi salah satu pertimbangan investor yang signifikan memengaruhi nilai perusahaan. Penelitian ketiga dilakukan oleh (Siallagan et al., 2018) yang menemukan bahwa profitabilitas berpengaruh negatif dan tidak signifikan terhadap nilai perusahaan pada Sub Sektor Farmasi yang terdaftar di Bursa Efek Indonesia periode 2013-2016. Penelitian keempat dilakukan oleh (Rukmawanti et al., 2019) Profitabilitas perusahaan berpengaruh negatif dengan nilai perusahaan PT. Indofood Sukses Makmur Tbk yang listed di Bursa Efek Indonesia tahun 2008-2017. Berdasarkan uraian dan perbedaan hasil penelitian di atas, untuk itu penulis ingin melakukan penelitian kembali terhadap variabel yang memengaruhi Price Book Value (PBV), yang menjadi pembeda dengan penelitian terdahulu adalah pada penelitian ini penulis menggunakan salah satu indikator rasio profitabilitas yaitu Return on Equity (ROE) pada perusahaan farmasi yang telah go publik di BEI periode 2014 sampai 2018. 


\section{B. KAJIAN PUSTAKA}

\section{Profitabilitas}

Profitabilitas menurut Entris (2013:51) dalam (Ukhriyawati \& Malia, 2018) adalah suatu usaha yang ditempuh oleh perusahaan untuk memberikan profit pada tahun buku tertentu. Rasio ini mencerminkan usaha yang digunakan untuk memberikan keuntungan kepada perusahaan, sehingga dapat menarik hati para penanam modal untuk menanamkan modalnya pada perusahaan. Hal ini dikarenakan apabila nilai profitabilitas tinggi akan meningkatkan keinginan investor terhadap harga saham perusahaan. Rasio profitabilitas yang pakai pada penulisan penelitian ini adalah Return on Equity (ROE). Rasio ini mencerminkan kemampuan organisasi perusahaan dalam penggunaan sumber daya yang dimiliki perusahaan untuk menghasilkan keuntungan yang diinginkan.

\section{Nilai Perusahaan}

Nilai perusahaan merupakan prestasi yang telah berhasil diraih oleh operusahaan. Perusahaan didirikan dengan tujuan untuk menghasilkan keuntungan untuk penanam modal dengan melihat harga saham yang dimiliki. Apabila harga saham tinggi, maka akan meningkatkan nilai perusahaan tersebut, sehingga dapat membuat investor berpandangan positif atau yakin dengan kinerja yang dimiliki perusahaan dan kemajuan perusahaan pada periode mendatang. Dengan tingginya nilai perusahaan dan harga saham, maka kesejahteraan pemegang saham akan terwujud. Dalam penelitian ini nilai perusahaan diwakilkan dengan dengan indikator Price To Book Value (PBV). Salah satu peneliti yaitu (Robiyanto et al., 2020) menjelaskan bahwa PBV dapat menilai kinerja suatu perusahaan dengan cara membandingkan harga saham perusahaan dengan nilai buku yang dimiliki. Biasanya perusahaan yang baik mempunyai nilai PBV melebihi satu, yang menjelaskan bahwa perusahaan mempunyai nilai pasar saham lebih tinggi dibandingkan nilai bukunya (Oktrima, 2017).

\section{METODE PENELITIAN}

Data yang dipakai pada penelitian ini adalah sekunder yang berupa laporan keuangan perusahaan farmasi. Tempat penelitian ini berada di Jakarta yaitu pada Bursa Efek Indonesia (BEI) dengan cara mengunjungi website http://www.idx.co.id dan dari Indonesia Capital Market Directory (ICMD). Waktu pengambilan data dalam penelitian ini dilakukan dari tahun 2014 hingga tahun 2018. Penelitian ini menggunakan populasi semua perusahaan yang tercatat dalam Bursa Efek Indonesia (BEI) periode 2014 sampai 2018, dengan sampel yang digunakan adalah perusahaan Farmasi yang berjumlah 8 perusahaan. Metode atau teknik pengambilan sampel yang digunakan adalah cluster sampling yang menyatakan bahwa populasi bukan terdiri dari individu atau tunggal tapi merupakan kesatuan atau kelompok (Subhan, 2014). Adapun kriteria yang digunakan sebagai berikut:

1. Populasi luas dengan karateristik umumberagam namun di dalamnya mengandung kelompok yang bersifat seragam.

2. Masing-masing kelompok merupakan representasi dari kesluruhan populasi. 
3. Tiap grup memilikijumlah anggota tetap dan eksklusif.

Data yang dipakai pada penelitian ini adalah bukti data sekunder yang berupa laporan keuangan. Analisis data dalam penelitian ini menggunakan regresi linear sederhana.

Variabel yang dipakai pada penelitian terdiri dari yang pertama nilai perusahaan. Variabel nilai perusahaan diwakilkan oleh rasio Price To Book Value (PBV). PBV merupakan perbandingan antara market value perusahaan dengan book value saham perusahaan. Untuk menghitung nilai PBV dihitung dengan menggunakan rumus (Firdaus, 2020):

$$
P B V=\frac{\text { Market Price per Share }}{\text { Book Value per Share }}
$$

Variabel kedua yang digunakan adalah Profitabilitas. Profitabilitas yaitu salah satu rasio yang dipakai dalam menilai usaha perusahaan-perusahaan untuk mewujudkan keuntungan yang diharapkan. Rasio profitabilitas yang dipakai pada penelitian adalah Return on Equity (ROE). ROE adalah salah satu rasio pengukuran yang dipakai untuk mengukur sejauh mana kemampuan ekuitas suatu perusahaan memanfaatkan skill yang dimiliki untuk menghasilkan laba, sehingga keefektifan kinerja perusahaan dalam memanfaakan aset dan modal yang dimiliki perusahaan akan terlihat (Robiyanto et al., 2020). ROE dihitung dengan menggunakan rumus:

$$
R O E=\frac{\text { Laba Bersih }}{\text { Total Ekuitas }}
$$

Selain dari data nilai ROE dan PBV dari tahun 2014-2018 yang digunakan dalam penelitian ini. Pada tabel di bawah ini juga dapat dilihat nilai ROE dan PBV perusahaan farmasi untuk tahun 2012-2013 sebagaiman ayang disajikan pada Tabel 1 dan Tabel 2.

Tabel 1.

Nilai ROE Perusahaan Farmasi tahun 2012-2013

\begin{tabular}{clccc}
\hline NO & PERUSAHAAN & $\mathbf{2 0 1 2}$ & $\mathbf{2 0 1 3}$ & RATA- RATA \\
\hline 1 & DVLA & 17,7 & 13,8 & 15,75 \\
2 & SIDO & 14,2 & 15,5 & 14,85 \\
3 & KLBF & 24,1 & 23,2 & 23,65 \\
4 & KAEF & 14,3 & 13,3 & 13,8 \\
5 & SCPI & $-71,5$ & $-11,7$ & $-41,6$ \\
6 & MERK & 8,17 & 8,27 & 8,22 \\
7 & PYFA & 1,08 & 8,84 & 4,96 \\
8 & TSPC & 4,99 & 3,79 & 4,39 \\
\hline \multicolumn{5}{c}{ Sumber: data diolah }
\end{tabular}

Sumber: data diolah 
Tabel 2.

Nilai PBV Perusahaan Farmasi Tahun 2012-2013

\begin{tabular}{clccc}
\hline NO & PERUSAHAAN & $\mathbf{2 0 1 2}$ & $\mathbf{2 0 1 3}$ & RATA-RATA \\
\hline 1 & DVLA & 2,25 & 2,70 & 2,48 \\
2 & SIDO & 3,67 & 3,99 & 3,83 \\
3 & KLBF & 7,30 & 6,90 & 7,1 \\
4 & KAEF & 2,85 & 2,08 & 2,47 \\
5 & SCPI & 6,51 & 10,05 & 8,28 \\
6 & MERK & 8,17 & 8,27 & 8,22 \\
7 & PYFA & 1,08 & 0,84 & 0,96 \\
8 & TSPC & 4,99 & 3,77 & 4,38 \\
\hline \multicolumn{5}{c}{ Sumber: Data diolah }
\end{tabular}

Nilai profitabilitas yang diwakilkan dengan ROE dan nilai perusahaan yang diwakilkan dengan PBV pada perusahaan farmasi yang tercatat di BEI tahun 2014 sampai 2018 ada pada tabel berikut ini.

Tabel 3.

Nilai ROE Perusahaan Farmasi Tahun 2014-2018

\begin{tabular}{clcccccc}
\hline NO & PERUSAHAAN & $\mathbf{2 0 1 4}$ & $\mathbf{2 0 1 5}$ & $\mathbf{2 0 1 6}$ & $\mathbf{2 0 1 7}$ & $\mathbf{2 0 1 8}$ & $\begin{array}{c}\text { RATA- } \\
\text { RATA }\end{array}$ \\
\hline 1 & DVLA & 8,41 & 11,8 & 14,09 & 14,53 & 16,72 & 13,11 \\
2 & SIDO & 15,76 & 9,47 & 9,61 & 18,43 & 22,87 & 15,23 \\
3 & KLBF & 21,74 & 18,81 & 18,86 & 17,66 & 16,33 & 18,68 \\
4 & KAEF & 14,98 & 13,59 & 11,96 & 12,89 & 11,96 & 13,08 \\
5 & SCPI & 47,01 & 42,66 & 73,68 & 34,30 & 25,30 & 44,59 \\
6 & MERK & 32,78 & 30,10 & 26,40 & 23,51 & 31,51 & 28,86 \\
7 & PYFA & 2,74 & 3,05 & 4,88 & 6,55 & 1,48 & 3,74 \\
8 & TSPC & 11,53 & 9,74 & 12,58 & 12,02 & 13,24 & 9,82 \\
\hline \multicolumn{7}{c}{ Sumber :Data diolah }
\end{tabular}

Pada Tabel 3 dapat dilihat bahwa rata rata nilai ROE mengalami kenaikan dan penurunan yang fluktuatif, hal ini dikarenakan juga oleh nilai ROE setiap tahun yang berfluktuatif mengalami peningkatan dan penurunan yang signifikan. Ini diduga adanya penurunan laba bersih yang diikuti juga oleh penurunan total aset.

Tabel 4.

Nilai PBV Perusahaan Farmasi Tahun 2014-2018

\begin{tabular}{clcccccc}
\hline NO & PERUSAHAAN & $\mathbf{2 0 1 4}$ & $\mathbf{2 0 1 5}$ & $\mathbf{2 0 1 6}$ & $\mathbf{2 0 1 7}$ & $\mathbf{2 0 1 8}$ & $\begin{array}{c}\text { RATA- } \\
\text { RATA }\end{array}$ \\
\hline $\mathbf{1}$ & DVLA & 1,5 & 1,84 & 1,95 & 1,81 & 1,91 & 1,8 \\
$\mathbf{2}$ & SIDO & 3,18 & 3,05 & 2,99 & 4,27 & 4,16 & 3,53 \\
$\mathbf{3}$ & KLBF & 5,55 & 6,01 & 5,94 & 4,89 & 5,14 & 5,51 \\
$\mathbf{4}$ & KAEF & 2,59 & 6,84 & 5,83 & 5,19 & 5,88 & 5,27 \\
$\mathbf{5}$ & SCPI & 1,03 & 0,38 & 0,28 & 0,23 & 0,23 & 0,43 \\
$\mathbf{6}$ & MERK & 6,41 & 7,44 & 6,24 & 3,02 & 3 & 5,22 \\
$\mathbf{7}$ & PYFA & 0,59 & 1,03 & 0,9 & 0,89 & 0,8 & 0,84 \\
$\mathbf{8}$ & TSPC & 1,82 & 1,94 & 1,66 & 1,17 & 1,28 & 1,57 \\
\hline \multicolumn{7}{c}{ Sumber: Data diolah }
\end{tabular}

Sumber: Data diolah 
Pada Tabel 4 dapat dilihat bahwa rata rata PBV mengalami kenaikan dan penurunan yang signifikan, hal ini dikarenakan juga oleh nilai PBV setiap tahun yang berfluktuatif mengalami kenaikan dan penurunan. Jadi dapat dilihat secara rata-rata nilai PBVnya mengalami penurunan, hal ini bisa disebabkan oleh adanya penurunan harga saham yang diikuti juga dengan penurunan nilai buku.

Hipotesis yang diajukan pada penelitian ini adalah terdapat pengaruh Return on Equity (ROE) terhadap Price To Book Value (PBV) Perusahaan Farmasi yang tercatat di Bursa Efek Indonesia tahun 2014-2018.

\section{HASIL DAN PEMBAHASAN}

\section{Uji Asumsi Klasik}

Uji normalitas bertujuan untuk mengetahui apakah model regresi yang digunakan berdistribusi normal. Uji normalitas dilihat dengan histogram atau probabilitas plot. Berdasarkan hasil pengujian normalitas data yang telah dilakukan, maka dapat disimpulkan data yang digunakan dalam penelitian ini terdistribusi normal. Hal Ini dibuktikan dengan histogram yang poligonnya tidak menceng ke kiri ataupun ke kanan dan hasil probability plot yang menunjukkan titik-titik menyebar digaris diagonal.

Uji multikolinearitas menggunakan Varian Inflation Faktor (VIP). Model regresi yang digunakan dalam penelitian ini terbebas dari multikolinearitas, karena semua variabel memiliki nilai tolerance di atas 0,1 dan nilai VIP dibawah 10.

Singgih Santoso (2008:219) dalam (Septariani, 2015) menjelaskan bahwa syarat tidak adanya autokorelasi adalah $-2<\mathrm{dw}<2$, apabila nilai dw berada di antara -2 dan +2 artinya tidak terjadi autokorelasi. Berdasarkan hasil pengujian didapatkan nilai Durbin Watson 1,614 dimana nilai ini terletak antara angka -2 dan +2 , sehingga tidak terjadi autokorelasi dalam penelitian ini

Berdasarkan scatterplott titik-titik menyebar dengan acak dan tersebar di atas ataupun dibawah angka nol pada sumbu Y, dengan demikian dapat dikatakan tidak terdapat heteroskedastisitas dalam model yang digunakan.

\section{Pengujian Hipotesis}

Berdasarkan hasil pengujian secara parsial, maka diperoleh persamaan regresinya $\mathrm{Y}=3,086-0,003 \mathrm{X}+\mathrm{e}$. Dari hasil perhitungan yang telah dilakukan diperoleh nilai $\mathrm{R}$ square sebesar 0,418 atau $(41,8 \%$ ) yang menunjukkan bahwa Price To Book Value (PBV) dapat dijelaskan oleh variable Return on Equity (ROE) sebesar 41,8\%, sedangkan 58,2\% dipengaruhi oleh faktor lain yang tidak dijelaskan dalam penelitian ini. Berdasarkan hasil uji t yang dilakukan diperoleh nilai thitung bertanda negatif sebesar - 0,126 dengan nilai sigifikannya 0,900 dimana lebih besar dari $0,05(0,900>0,05)$, yang berarti hipotesis ditolak dimana variabel independen Return on Equity (ROE) mempunyai pengaruh negatif dan tidak signifikan terhadap variabel dependen Price To Book Value (PBV). Jadi pada penelitian ini tidak ditemukan bukti yang empiris yang mengatakan bahwa jika nilai profitabilitas perusahaan mengalami peningkatan maka nilai perusahaan juga mengalami peningkatan. Berarti hasil penelitian yang telah dilakukan bertolak belakang dengan teori yang ada. Hal ini bisa terjadi apabila laba bersih perusahaan atau net income 
mengalami penurunan dan terjadinya penurunan atau tetap untuk nilai ekuitasnya. Hal ini bisa juga terjadi net income dan ekuitas sama-sama mengalami penurunan. Penelitian ini sejalan dengan penelitian yang dilakukan oleh (Robiyanto et al., 2020) yang menyatakan bahwa profitabilitas yang diwakilkan dengan ROE dan ROA secara signifikan berdampak negatif terhadap nilai perusahaan yang diwakilkan dengan PBV akan tetapi tidak berpengaruh pada nilai perusahaan yang diproksikan Tobin's Q. Penelitian ini juga didukung oleh penelitian yang telah dilakukan (Ukhriyawati \& Malia, 2018) yang menyatakan bahwa profitabilitas tidak memiliki pengaruh yang signifikan terhadap nilai perusahaan sektor kimia yang tercatat di BEI pada tahun 2013 sampai 2016. Penelitian yang dilakukan (Tandanu \& Suryadi, 2020) juga menemukan bahwa variabel profitabilitas tidak memiliki hubungan yang signifikan terhadap nilai perusahaan. Lain halnya dengan hasil temuan (Kusumawati \& Rosady, 2018) yang menyatakan bahwa profitabilitas berpengaruh positif dan signifikan dengan nilai perusahaan.

\section{E. SIMPULAN}

Berdasarkan penelitian yang telah dilakukan maka disimpulkan bahwa variabel profitabilitas yang diwakilkan dengan rasio Return on Equity (ROE) tidak berpengaruh terhadap nilai perusahaan yang diwakilkan dengan rasio Price To Book Value (PBV) yang dibuktikan dengan nilai signifikannya lebih besar dari probabilitas $0,05(0,900>0,05)$ dengan nilai thitung $=-0,126$ dan $t_{\text {tabel }}=1,686(-0,126$ $<$ 1,686). Jadi pada penelitian ini tidak ditemukan bukti yang empiris yang mengatakan bahwa jika nilai profitabilitas perusahaan mengalami peningkatan maka nilai perusahaan juga mengalami peningkatan. Berarti hasil penelitian yang telah dilakukan bertolak belakang dengan teori yang ada. Hal ini bisa terjadi apabila laba bersih perusahaan atau net income mengalami penurunan dan terjadinya penurunan atau tetap untuk nilai ekuitasnya. Hal ini bisa juga terjadi jika net income dan ekuitas sama-sama mengalami penurunan.

Untuk peneliti selanjutnya yang tertarik melakukan penelitian tentang profitabilitas dan nilai perusahaan, diharapkan agar menambahkan variabel independen lainnya seperti likuiditas, ukuran perusahaan dan mengubah objek penelitian yang digunakan seperti perusahaan non manufaktur agar hasil penelitian lebih baik lagi. 


\section{DAFTAR PUSTAKA}

Deborah, N. K., \& Marsudi, A. S. (2013). Peran Kebijakan Dividen Pada Pengaruh Profitabilitas Terhadap Nilai Perusahaan (Studi Empiris Pada Perusahaan Manufaktur Di Indonesia Tahun 2015-2017). Journal of Chemical Information and Modeling, 53(9), 1689-1699.

Fernandes Moniaga. (2013). Struktur Modal, Profitabilitas Dan Struktur Biaya Terhadap Nilai Perusahaan Industri Keramik, Porcelen Dan Kaca Periode 2007 - 2011. Jurnal EMBA, Vol.1 No 4(4), Hal. 433-442.

Firdaus, I. (2020). The Effect of DER, TATO, ROA and Share Price to PBV (Studies on the food and beverage industry on the Indonesia Stock Exchange period of 2012-2018). Dinasti International Journal of Digital Business Management, 1(2), 210-223.

Hauteas, O. S., \& Muslichah. (2019). Analisis Pengaruh Profitabilitas dan Kebijakan Dividen Terhadap Nilai Perusahaan dengan Struktur Modal sebagai Variabel Mediasi. Jurnal Manajemen Dan Keuangan, 8(2), 177-192.

Indriawati, I., Ariesta, M., \& Santoso, E. B. (2018). Pengaruh Profitabilitas,Keputusan Investasi, Pertumbuhan Perusahaan Terhadap Nilai Perusahaan Dengan Kebijakan Deviden Sebagai Variabel Intervening Pada Perusahaan Manufaktur Food and Beverage yang Terdaftar Di Bursa Efek Indonesia Tahun 2012 -2016. Journal of Accounting, 1-19.

Kusumawati, R., \& Rosady, I. (2018). Pengaruh Struktur Modal dan Profitabilitas terhadap Nilai Perusahaan dengan Kepemilikan Manajerial sebagai Variabel Moderasi. Jurnal Manajemen Bisnis, 9(2), 147-160.

Lubis, I. L., Sinaga, B. M., \& Sasongko, H. (2017). Pengaruh Profitabilitas, Sruktur Modal, Dan Likuiditas Terhadap Nilai Perusahaan. Jurnal Aplikasi Bisnis Dan Manajemen, 3(3), 458-465.

Ndruru, M., Silaban, P. B., Sihaloho, J., Manurung, K. M., \& Sipahutar, T. T. U. (2020). Pengaruh Likuiditas, Leverage, Dan Profitabilitas Terhadap Nilai Perusahaan Pada Perusahaan Manufaktur Tahun 2015-2017. Jurnal Ilmiah MEA (Manajemen, Ekonomi, Dan Akuntansi), 4(3), 390-405.

Oktaviarni, F., Murni, Y., \& Supriatno, B. (2019). Pengaruh Profitabilitas, Likuiditas, Leverage, Kebijakan Dividen, Dan Ukuran Perusahaan Terhadap Nilai Perusahaan. Jurnal Akuntansi, 9(1), 1-16.

Oktrima, B. (2017). Pengaruh Profitabilitas, Likuiditas, dan Struktur Modal terhadap Nilai Perusahaan (Studi Empiris: PT. Mayora Indah, Tbk. Tahun 2011 - 2015). 1(1), 98-107.

Robiyanto, R., Nafiah, I., Harijono, H., \& Inggarwati, K. (2020). Pengaruh Profitabilitas Terhadap Nilai Perusahaan Perhotelan Dan Pariwisata Dengan Struktur Modal Sebagai Variabel Intervening. Jurnal Ilmiah Bisnis Dan Ekonomi Asia, 14(1), 46-57. 
Rukmawanti, L., Enas, E., \& Lestari, M. N. (2019). Pengaruh Ukuran Perusahaan Dan Profitabilitas Terhadap Nilai Perusahaan (Suatu Studi Pada PT . Indofood Sukses Makmur Tbk Tahun 2008-2017). Business Management and Entrepreneurship Journal, 1(2), 158-173.

Septariani, D. (2015). Pengaruh financial ratios dan size terhadap Price To Book Value. Journal of Applied Business and Economics, 2(2), 134-150.

Siallagan, M. E. P., Siahaan, Y., Jubi, J., \& Inrawan, A. (2018). Pengaruh Profitabilitas Terhadap Nilai Perusahaan Dengan Leverage Sebagai Variabel Moderating Pada Perusahaan Sub Sektor Farmasi Yang Terdaftar Di Bursa Efek Indonesia. SULTANIST: Jurnal Manajemen Dan Keuangan, 6(2), 1-8.

Subhan, M. (2014). Pengaruh Pengetahuan Mengenai Risiko dan Kompetensi terhadap Kinerja Underwriter Perusahaan di Industri Asuransi Kerugian (Umum) di Indonesia. Jurnal MIX, IV(1), 83-89.

Tandanu, A., \& Suryadi, L. (2020). Pengaruh Profitabilitas, Likuiditas, Ukuran Perusahaan, Terhadap Nilai Perusahaan. Jurnal Multiparadigma Akuntansi Tarumanagara, 2(1), $108-117$. https://journal.untar.ac.id/index.php/jpa/article/download/7138/4704

Ukhriyawati, C. F., \& Malia, R. (2018). Pengaruh profitabilitas, keputusan Investasi dan Kebijakan Hutang Terhadap Nilai Perusahaan Pada Perusahaan Sub Sektor Kimia Yang Terdaftar di BEI. Jurnal Bening Prodi Manajemen Universitas Riau Kepulauan Batam, 5(1), 14-26.

Wibowo, R., \& Aisjah, S. (2011). Pengaruh profitabilitas, kepemilikan manajerial, kebijakan dividen, dan leverage terhadap nilai perusahaan.

Yansi, Rinnaya Ista Rita Andini, A. O. (2016). Pengaruh Profitabilitas, Rasio Aktivitas, Keputusan Pendanaan, Keputusan Investasi Terhadap Nilai Perusahaan (Studi Empiris pada Perusahaan Manufaktur yang Terdaftar di BEI Tahun 2010-2014). Journal Of Accounting, 2(2), 1-18. 